International Journal of Social Science And Human Research

ISSN(print): 2644-0679, ISSN(online): 2644-0695

Volume 04 Issue 10 October 2021

DOI: 10.47191/ijsshr/v4-i10-53, Impact factor-5.586

Page No: 3056-3062

\title{
Desistance From Terrorism a New Hope for the Quit from Terrorism Program Indonesia
}

\author{
Ardi Putra Prasetya ${ }^{1}$, Adrianus E Meliala ${ }^{2}$ \\ ${ }^{1,2}$ University of Indonesia
}

\begin{abstract}
This paper contains an alternative to counter-terrorism in Indonesia, Desistance from Terrorism. Indonesia has a long history of acts of terror, starting in the 40s until now. Regulation No. 5 of 2018 became one of the points where Indonesia started a soft approach program. The approach taken is deradicalization which triggers many reactions among the community or targets. Desistance from terrorism gives a new color to the program to leave the terror group. When experts and academics are trapped in the concept of deradicalization or disengagement, desistance from terrorism emerges by bringing different approaches and concepts. This paper discusses the advantages and disadvantages of implementing desistance in Indonesia. The argument about desistance from terrorism is built from various opinions and has been previously studied by several academics
\end{abstract}

KEYWORDS: desistance; desistance from terrorism; Counter-Terrorism; de-radicalization; disengagement

\section{INTRODUCTION}

\section{Indonesia Terrorism Background}

Historically, Indonesia has had a close relationship with the existence of terror groups. According to a report issued by the International Crisis Group (IGC) to understand the problem of terrorism in Indonesia, it is necessary to know the emergence of the Darul Islam movement (DI) and the efforts to establish an Islamic State of Indonesia (NII). The NII movement has produced various fragments and splinters, ranging from Jamaah Islamiyah (JI) to religious groups that reject violence. Every time the old generation disappears, a new generation of militants emerges who receive the East Indonesia Mujahidin (MIT) group, which is proof that a new militant movement is reborn and becomes the successor of the inspiration to form the NII. In 2012, MIT was founded by Santoso who is a member of JI. But not many wanted to join the MIT group led by Santoso. The cause was the Syrian conflict which broke into three major groups throughout the country. One of them is a group of Islamic fighters such as Jabhat Nusrah and Jaisy Muhajirin wal Ansar. In the end, it gave birth instead of an Islamic state covering the territory of Iraq and Syria called the Islamic State of Iraq and Sham (ISIS). ISIS was born from the process of separating the leadership of Central Al-Qaeda by Abu Bakr AlBaghdadi who was the former leader of the Al-Qaeda branch in Iraq (Zulfahri, 2020).

The Indonesian government has committed itself to carry out wars on terrorism through the issuance of Law No. 15 of 2003 concerning the Eradication of Criminal Acts of Terrorism. Law No. 15/2003 in carrying out law enforcement against various acts of terror uses the triangle approach paradigm which consists of protecting, defend state interests, protecting the offender, and protecting and rehabilitate the victims (BPHN, 2011). The success of eradicating through Law No. 15/2003 has succeeded in gaining international recognition, especially since the perpetrators and terrorist networks of the Bali Bombing I and Bali Bombing II have been revealed by the Indonesian Police (Aji, 2013).

The direction of counter-terrorism policies in Indonesia is shifting following the dynamics of terrorist groups that continue to develop. In general, it takes various forms, ranging from foreign fighters (terrorists operating in other countries), home-grown terrorism (terrorism based in Indonesia) to the most actual and dominant today, lone-wolf terrorism ( Ansori, 2019). In addition, there is an increasing trend of terrorist attacks by groups that are considered stylish, such as MIT, Jamaah Anshaarut Tauhid (JAT), and JAD. The following data describes the latest trends in terrorism attacks in Indonesia by group networks (Indonesian Terrorism and Counter-Terrorism Database, 2020)

\section{Soft Approach Program in Indonesia}

According to Law 5/2018, Indonesia also uses a soft approach, which is in direct contact with social, political, communication, and ideological dimensions (Ansori, 2019). In the soft approach, the recovery stage is provided through a deradicalization program in which there is a disengagement process (soft approach). Deradicalization is the process of moderating one's radical ideology. According to Kruglansi, the main target of the deradicalization program is to reverse the belief system that 


\section{Desistance From Terrorism a New Hope for the Quit from Terrorism Program in Indonesia}

supports violence and is considered successful if former terrorists think that radical means (eg acts of violence) are morally unacceptable, ineffective, and do not provide any benefits. (Horgan, 2008).

In individual deradicalization, it takes achievement of the disengagement process. Because deradicalization is more of an effort to change cognitive understanding so as not to become radical. Meanwhile, disengagement is the process of changing a person's behavior by restraining him from committing acts of violence and pulling him out of radical organizations (Zulfahri, 2020). Disengagement has the aim of releasing someone from radical actions and breaking the chain of religious extremism groups. Because, people who have been deradicalized may be still helping religious extremism groups, by justifying the act of jihad in certain events.

However, so far the effectiveness of the deradicalization program has not reached the emergence of the disengagement process. Because according to Horgan (2009) in his book Leaving Terrorism Behind considers that it is unrealistic to rely on deradicalization in the strategy of dealing with terrorism. According to Horgan (2009), the state strategy should focus on disengagement or severing the attachment of terrorist members to terrorist networks, including cutting off all access to acts of terrorist violence. However, Rabasa et al (2010) suggest that deradicalization should still be the main goal because it will result in more permanent changes and significantly reduce the likelihood of recidivism. However, disengagement also remains an important part of the counter-terrorism strategy.

In addition, Sumpter (2017) explains that the deradicalization program by the Government is less effective because it is implemented with a top-down approach without considering cooperation with communities who have strong grassroots networks, direct experience, and legitimacy requirements for dealing with ex-terrorists. In line with this, several studies have noted that community attitudes affect the success of deradicalization programs (Abuza, 2009; Syariq: 2019). Indeed, as Bjorgo (2009) points out, the availability of alternatives to normal life and identity within the wider society for former members of an extremist group will determine permanent status and release from violent extremism. Therefore, the deradicalization program must be supported by building relationships between former perpetrators of jihadist violence with civil society activists and trusted figures from the wider Muslim community as well as providing economic activities that become an alternative source of livelihood for former terrorists and their families (Chalmers, 2017 ).

When the deradicalization program does not achieve its objectives, it will have an impact on the emergence of recidivist terrorism cases in Indonesia. This is reinforced by the findings of the case by the National Police Headquarters which stated that two of the five perpetrators of the terrorist attack in Sarinah (2016) were free recidivist terrorism cases in 2014. This was also reinforced by the finding of recidivist terrorism rates in Indonesia by IPAC (2020). Moreover, no conclusions can be drawn with confidence about how successful this deradicalization program is due to the lack of empirical data and good evidence of what has been done (Silke \& Veldhuis, 2017). Moreover, according to Horgan (2014) whether or not a person is radical is difficult to measure. Therefore, when a former terrorist has finished serving his sentence, it is very difficult to predict and map out whether that person has ended his involvement, is still waiting for the moment, or is already planning to carry out another terror act.

Terrorism analyst in the United States, Dennis Pluchinsky notes that there is a real tendency for global jihadis to become recidivist and that the propensity for reform is less likely for global jihadists than for secular terrorists. This is in line with research by Altier, Boyle, and Horgan (2017) who have studied the autobiographies of individuals involved in terrorist activities affiliated with known perpetrator groups and came to the conclusion that terrorist re-engagement and recidivism rates are relatively high and even slightly higher than the rates of terrorist re-engagement and recidivism. criminal recidivism (Altier, Boyle, \& Horgan, 2017). This shows that convicted jihadists are indeed more dangerous than secular terrorists and the recidivism rate among them is close to that of ordinary criminals, so significant problems are looming.

In addition, data found by IPAC showed that the recidivism rate was 11.4 percent. This is an increase compared to 2013, where the recidivism rate for terrorism cases was 10 percent. According to Rosenfeld (2008), the rate of criminal recidivism is generally poor concerning how well it is doing to rehabilitate offenders. The existence of a high recidivist rate has shown that offenders do not receive rehabilitation and that most first-time offenders usually quit, so the ideal criminal justice system should provide prisons for those who cannot be rehabilitated by other means, will have a high influence on recidivism rates (Rosenfeld, 2008).

Furthermore, answers to the question of the prevalence of terrorism recidivism are often given in response to evaluations of existing "deradicalization" programs or the need for indefinite detention. Even Wright's (2019) findings suggest that something has changed would-be jihadis in prison and that change cannot be attributed to the nationally coordinated CVE or deradicalization programs in the United States. Since the desire to escape radicalism and the willingness to commit further crimes is the result of something else (Wright, 2019).

As explained by Monahan (2012) focuses on assessing the risk of terrorism after undergoing formal sanctions. Monahan (2012) identified four potential risk factors for terrorism, namely ideology, affiliation, personal or group grievances, and moral emotions. However, Monahan (2012) rightly reiterates how the risk factors associated with one's initial incursion into terrorism may differ from the risk factors for re-engagement. In addition, the potential risk factors for re-engagement may also vary with the individual's role (such as the bomber, lone actor, and messenger) or level of involvement. It is also possible that the risk factors for 


\section{Desistance From Terrorism a New Hope for the Quit from Terrorism Program in Indonesia}

re-engagement for incarcerated or detained individuals (i.e. risk factors for recidivism) may differ from the risk factors for reengagement for those whose decision to release is voluntary (Monahan, 2010).

However, relying on the recidivism rate as an indicator of full success would be very difficult. Because terrorism recidivism is not adequately defined, there is no consensus on its measurement, and it lacks a basic level of re-engagement among terrorists without intervention. According to Altier and Horgan (2012), this is due to the lack of research on recidivism in the context of terrorism. Until now, the measurement of terrorism recidivism is still using ordinary criminal recidivism measurements, as done by Altier and Horgan.

\section{Desistance from Terrorism as an Alternative}

Laub and Sampson (2001) in their research showed small differences in the definitions of recidivism and desistance. In addition, many criminologists agree that criminal acts are conceptualized as a dynamic process rather than a static event (Weitekam $\&$ Kerner, 1994). This shows how the researcher will understand the process. Weitekam and Kerner (1994) describe termination in crime as a decrease in the frequency and variety of offenses committed up to the point of termination, which is defined as the permanent cessation of criminal activity. Then, Laub and Sampson (2001) also view termination as a gradual transition out of criminal behavior. However, it still maintains that the termination continues the termination point. This view is echoed by Farrall and Maruna (2004) who distinguish between primary cessation or pause in criminal activity during the course of a person's life and secondary cessation, which is characterized by permanent cessation of criminal activity and changes at the personal level of identity (Farrall \& Maruna, 2004).

Therefore, desistance from crime studies has helped measure a person's level of recidivism. Because the problem of measuring recidivism can be measured by the occurrence of an event, namely criminal activity. However, most studies of recidivism use a relatively short follow-up period of about six months to three years. While it is true that most will re-offend to do so within the first days, weeks, and months after release from custody (Langan \& Levin, 2002; National Research Council, 2007), it is also true that more individuals may return to criminal activity. later in life in post-life measurements (Brame \& Bushway, 2003; Laub \& Sampson, 2003).

Experts have responded to the measurement problem in various ways. Some, for example, Farrington \& Hawkins (1991) suggest studying persistence as approximating the long-term cessation of criminal activity, while others propose that cessation requires cessation of offending (Clarke \& Cornish, 1985). Others such as Berg \& Huebner (2011) examined the timing of recidivism using the survival model, which explains the fact that one cannot observe whether one will re-offend in the future or not.

Despite the differences in approach, most investigators agree that increasing the length of the follow-up period and collecting data at shorter and more frequent intervals over a significant period is critical to improving measures of recidivism and resistance. A study conducted by the National Research Council (2007), stated that it would be useful for policymakers to know when the time between violations increased or whether crimes committed became less serious as a result of certain interventions or treatments.

In this context, desistance from terrorism has an important role to dissect and explore how a person ends a period of involvement in acts of terrorism. The concept of desistance from terrorism is more widely understood as a reduction or reduction in substantial attacks, rather than as the absence of terrorism attacks at all. Downsizing theorists have noted that it is difficult to determine when the terrorist threat is reduced to zero (LaFree \& Miller, 2008). Therefore, desistance from terrorism is a behavior to take a distance from the activities of terrorist groups, both in ideology and in action.

As with desistance from crime in general, this desistance from terrorism also has a process, according to Laub and Sampson, there is a turning point that functions to turn an individual into resistance. According to LeBlanc and Frechette (1989), there are four sub-components of persistence that can apply to terrorism cases. Among other things, there is de-escalation, which occurs when a criminal commits a crime that is less serious than the crime he has committed before; deceleration refers to the frequency or time a person commits a crime; reaching a ceiling is when the offender reaches the highest limit in the number of crimes committed; Specialization is when the perpetrator becomes more specialized in committing a particular type of crime.

Resistance to terrorism relies on a process that goes beyond the identification of radical and social understanding. Rather, it also involves ownership of resources to leave terrorist groups and network structures (Raets, 2018). This is related to the terrorist disengagement that needs to be fulfilled so that the terrorists stop violent activities. To realize terrorist disengagement, a push factor is needed during the beginning of the year stages of the renunciation process, and pull factors (pull factors) play an important role in the disaffiliation (the act of abandoning belief) of a particular religion. Push factors consist of unfulfilled expectations, disappointment with terrorist organizations, difficulty adapting to a clandestine lifestyle, inability to cope with psychological effects. While the pull factors consist of competition, positive interactions, educational demands or opportunities, family building, financial incentives, and amnesty (Altier, Throughgood, \& Horgan, 2014).

Furthermore, the process of persistence from terrorism is more dynamic. The process begins with a series of initial doubts, causing the individual to question and reconsider the role (role reinterpretation). The process is with a doubting stage that will be experienced by terrorists for years. Then, seeking and weighing alternatives, where individuals begin to search and evaluate roles. In this stage, it is influenced by moderating factors. Then, the terrorists can go to the turning point stage, where certain events have 


\section{Desistance From Terrorism a New Hope for the Quit from Terrorism Program in Indonesia}

mobilized and focused the awareness that acts of terrorism are no longer satisfying or tend to disturb the individual. Therefore, one of the most important things in looking at the process of changing a person's criminal behavior is to identify turning points. Until finally, the terrorists experience the post-exit stage, where individuals must build a new identity that integrates their previous roles. Thus, this stage is characterized by significant adjustment to reintegration. Identity change may occur in persistence, but it is the result of conventional role participation (hooks for a change). Where changes can provide important openings towards new identities and these hooks affect the shift in new identities (Altier, Throughgood, \& Horgan, 2014).

In addition, one of the methodologies in persistence from terrorism that can be useful for dealing with the problem of recidivism rates is trajectory analysis, which is understood as a group-based approach that models a dynamic developmental process by using classes to estimate a typical trajectory that follows an unknown distribution. and sustainable (Altier, Throughgood, \& Horgan, 2014), therefore, persistence from terrorism can be seen as a process. By doing so, researchers will be able to identify general patterns of activity over time for groups of actors and estimate how common they are. The results of the analysis describe various activity trajectories between groups of actors, ranging from "low peaks; rapid descent trajectory "to" high peaks; very slow decline." However, it can also reveal other complications related to the operationalization of terrorist organizations (Miller, 2016).

\section{DISCUSSION}

The background and condition of the problem of terrorism in Indonesia are understood by researchers through experience in the field to participate in dealing with terrorist crimes. In addition, theoretically, he has collected various scientific journal articles related to desistance from terrorism-related to this research. The main journal references that the author uses are Gary LaFree \& Erin Miller (2008), Sigrid Raets (2017), Clark McCauley (2009), Erin Miller (2014, 2016), and Mary Beth Altier, Christian N. Thoroughgood, \& John G. (2014).

Broadly speaking, the scientific journals used in this research can be divided into two categories, journals that contribute to theoretical thinking and journals that contribute to research on terrorist resistance directly. The theoretical framework comes from the thoughts of LaFree \& Miller, Raets, McCauley, Altier, Thoroughgood, and Horgan. As for the research on terrorist resistance directly using reference sources from McCauley and Miller.

The first journal used was an article by Gary LaFree and Erin Miller entitled Desistance from terrorism: What can we learn from Criminology? (2008). This journal explains that there is a strong relationship between criminological research and research on terrorism which is desirable for several reasons. First, as a form of illegal violence, terrorism is included in the scope of criminology, which includes "the process of making laws, breaking laws, and reacting to violations of the law." Second, while there are important conceptual differences between terrorism and more conventional types of crime, there are also many similarities in terms of theories, methods, patterns of abuse, and their effects on society; namely the argument that "terrorism is a form of evil in all important respects." Finally, the moralistic causes that often animate terrorist attacks do not occur in isolation but require resources and infrastructure that may depend on there are common criminal activities such as bank robberies, fraud, immigration violations, and smuggling.

The advantage of this research is that LaFree and Miller can identify and analyze various kinds of criminological theories that are useful for persistence research. In addition, the results of their analysis also include opening up more opportunities to develop the criminological theory for persistence research. This article is used as a rationale for understanding the persistence of crime from various perspectives. Because, as many researchers have argued, there is no single theory that can explain the persistence of crime.

Then the second is a journal article entitled Turning away from terrorism: Lessons from psychology, sociology, and criminology from Mary Beth Altier, Christian N. Thoroughgood, and John G. (2014). This article provides a multidisciplinary review of related research from psychology, sociology, and criminology using the push and pulls framework, Rusbult's investment model, and Ebaugh's voluntary role exit. Rusbult's investment model offers insight into when and why individuals escape terrorism while taking into account macro-level differences between individuals, groups in the satisfaction derived from engagement, investments expended, and available alternatives. Ebaugh's research on voluntary role exits provides a deeper understanding of how people leave, including the emotion and behavioral cues that may be involved. This article highlights the strengths and limitations of the framework in explaining exiting processes across various social roles, including the possible terrorist role, and provides additional insight into terrorist disengagement through a review of related research on resistance from crime.

The advantage of this article is that Altier et al can present a combination of various theories from three disciplines and their benefits for the development of persistence research. The results of the analysis show that individual disengagement from terrorism, apart from push and pull factors, can also be explained through Rusbult and Ebaugh's framework which focuses on individual and social explanations. The author uses this article as a frame of reference in understanding the disengagement program and how individuals can finally get out of terrorism.

The third journal used is from Sigrid Raets, namely The We in Me: Considering Terrorist Desistance from a Social Identity Perspective (2017). This article aims to address the urgent need for a better understanding of resistance from terrorism by introducing a social identity perspective. Social identity can be understood as that part of an individual's self-concept derived from membership in personally relevant social groups. Thus, the concept of social identity is very important to understand the transformation of 


\section{Desistance From Terrorism a New Hope for the Quit from Terrorism Program in Indonesia}

identity intrinsically to move away from terrorism. Exploring the role of social identity in the resistance from terrorists emphasizes the intersection between individuals and social groups.

The advantage of this article is that Raets can explain that identity, along with social structures and agencies play an important role in a person's resistance to terrorism. According to him, persistence from terrorism is separated by very different structural opportunities compared to the beginning of the terrorist life cycle. The process of resisting terrorism depends on processes that go beyond identification, particularly notions of structure and agency. In many cases, the acquisition of a particular social identity is encouraged and valued by the group, while the rejection of this identity is met with stigmatization and humiliation on both sides. In addition, desistance is also determined by the existence of opportunities and resources needed to withdraw from the organization. In short, the persistence of terrorists rests on the different interactions between identity processes, structures, and agents which in turn imply a completely different dynamic when compared to the early emergence of terrorists. The author uses this article as a reference for thinking about how individuals can be separated from their groups.

Next is a journal article from Clark McCauley entitled Dynamics of Asymmetric Conflict: Pathways toward terrorism and genocide (2009). This article discusses recent efforts to conceptualize group-level terrorism, identify relevant actors and actions in competing against terrorist groups and the governments they target and identify the various forms of resistance that can emerge from this competition. The review of resistance by LaFree and Miller highlights the importance of distinguishing between individual and group resistance. Case study of the persistence of terrorist groups by Wheatley \& McCauley (Egyptian Islamic Group) and Dugan et al (the Armenian Secret Army for the Liberation of Armenia and the Justice Commandos of the Armenian Genocide) shows that terrorist sympathizers and supporters sometimes generalize from the guilt of one terrorist group to disapproving of terrorism as a tactic for any group. However, what should be noted about the seven theories described by LaFree and Miller is that they are theories of the origin of crime as well as the theory of persistence of crime. The advantage of this theory is that McCauley can identify the advantages and disadvantages of various criminological theories and how they are useful for group-based resistance research. The author uses this article as a reference in understanding persistence from various points of view.

Next is the article entitled Patterns of Collective Desistance from Terrorism Fundamental Measurement Challenges by Erin Miller (2016). In this article, Miller wishes to increase the reader's empirical understanding of patterns of collective resistance from terrorism in support of a strong research agenda to advance theory and policy. Miller discusses two main challenges for empirical analysis of collective resistance from terrorism, namely the operationalization of the perpetrator's organization and the operationalization of collective resistance. It reveals diverse patterns of persistence and substantive variation among organizations classified as having similar trajectories. This finding is consistent with Crenshaw's observation that the effectiveness of counterterrorism operations tends to differ depending on the context. These results suggest that it is important for policymakers to consider historical patterns of activity not only among loosely organized offender organizations, but also hierarchically structured organizations, but also differ in terms of the degree of sporadic and specialization in abuses.

The advantage of this article is that Miller in conducting his research uses a quantitative approach. He draws on more than 40 years of event data from the Global Terrorism Database among organizations that carried out terrorist attacks between 1970 and 2013. The author uses this article to understand the process of group resistance and how other factors such as length of time affect the process.

Still using a quantitative approach, Erin Miller in her article entitled Patterns of Onset and Decline Among Terrorist Organizations (2012) explains that apart from speculation among terrorism researchers regarding the conditions that lead to the persistence of terrorist organizations, quantitative analysis of terrorism often focuses on the terrorist attack as a unit of analysis, thus causing almost no analysis of the terrorist organization itself. In addition, research on organizations involved in terrorism is generally limited to case studies of individual organizations. While most of the groups of offenders discussed in this article never reach high levels of activity or longevity, on average there are only a few attacks during their peak year and then decline rapidly.

The advantage of this article is that Miller has succeeded in analyzing the correlation between individual resistance from terrorism by looking at the pattern of decreasing terrorist activity at the organizational level from the beginning to reaching its peak of glory and then dropping again. The author uses this article as reference material to analyze the process of how the activities of terrorist groups can affect individual resistance.

In the end, this persistence from terrorism can provide a new color in dissecting how a person will end his involvement in terrorism, either temporarily or completely. Because in a person's persistence process, the social context will dominate and have an important role compared to subjective factors. This is in line with the views of Lynch \& Argonamiz (2017) that the social context factor will determine whether an individual stops completely from terrorism or not.

\section{CONCLUSION}

Indonesia uses two types of approaches, namely a soft approach and a hard approach based on Law 5/2018. It can be explained that the hard approach generally contains an offensive framework that includes the deployment of force or the military, a legal approach, and various policies and laws, as well as a defensive one, which includes all intelligence, infrastructure protection, and border 


\section{Desistance From Terrorism a New Hope for the Quit from Terrorism Program in Indonesia}

security efforts. While the soft approach is in contact with social, political, communication, and ideological dimensions (Ansori, 2019).

However, it was found that the soft approach implemented through the deradicalization program did not guarantee to prevent the emergence of recidivist behavior of terrorism crimes. Previous research by Supmter (2017) explained that the deradicalization program by the Government of Indonesia was less effective because it did not consider collaborating with community groups that already have strong grassroots networks, hands-on experience, and legitimacy requirements for dealing with ex-terrorists. Widya's research (2020) found that the deradicalization program did not work well because it had weaknesses related to the form of cooperation with institutions in Indonesia.

Other evidence also found that the deradicalization program had shown weaknesses and could backfire for the Government of Indonesia. One of the testimonies of one of the former supporters of terrorism who had undergone a deradicalization program was found, that the program did not promise anything that could support former terrorism to stop. Thus, making former terrorists rejoin the terrorist network (Levenia, 2020). Furthermore, Suarda's research (2016) found that the deradicalization program was not effective because the program did not have measurement criteria to identify its effectiveness.

Regarding the results of research by Suarda (2016), according to Horgan (2014), the degree of radicalism or not is difficult to measure. Therefore, when a former terrorist has finished serving his sentence, it is very difficult to predict and do a mapping, whether the former terrorism really ends his involvement, or is still waiting for the moment, or is already planning to carry out another terror act. Thus, the benchmark of radicalism becomes an absolute necessity. The absence of a clear benchmark for radicalism can cause various problems in countering terrorism in Indonesia. Because, the benchmark of radicalism is not only a tool to measure the success and failure of the deradicalization program, but also to provide a limit to the term radicalism itself. This is in line with the view of Sidney Jones (2015), that the Indonesian government's deradicalization program is still weak because there is no political agreement regarding what forms of radicalism are considered dangerous (Al-Chaidar, 2016).

Furthermore, the absence of measurement of the level of radicalism in the deradicalization program in Indonesia indicates that the government program has been trapped in the active participation of the target in the deradicalization program (Febriane, 2013). Therefore, the researcher on terrorism studies at the University of Indonesia (UI), Sapto Priyanto (2020) stated that the current deradicalization program does not look further whether the object has stopped carrying out or has the potential to return to carrying out terror acts so that all programs will be generalized. Even though there are unique things that should be considered by deradicalization organizers, they tend to be ignored (Priyanto, 2020). The current condition of the deradicalization program, which is still being maintained by the government, will give birth to terrorism recidivists. Priyanto (2020) shows that until December 2019, terrorist recidivists in Indonesia reached 52 people. The recidivist category involving 52 people has been proven to be involved in acts of terrorism in the first and second cases (Chairullah, 2020).

In addition, with the formation of recidivism behavior, the Indonesian government failed to form a pattern of resistance to terrorism. Quitting crime is a process that is in many ways similar to ending one's involvement in extremist activities (Raets, 2019). To create a pattern of persistence, a disengagement process is needed, which does not appear in the deradicalization program. Whereas the disengagement process can help release former terrorists from radical influences (Marsden, 2017). Hasan (2020) explains that the success and failure of these programs, policymakers need to clearly understand the difference between termination, disengagement, and deradicalization, and the importance of adopting this approach according to the level of risk posed.

Developing a stage to establish desistance from terrorism, can help minimize recidivism behavior. Because basically, desistance is when someone chooses not to commit violence or other illegal acts. This may be due to a lack of courage to challenge the law, or due to effective deterrence by the criminal justice system. Doubts about the possibility or viability of violence to achieve ideological goals can also cause a person not to take action to stop but instead suffice with problematic cessation (failing to stop) because former terrorists still hold an extremist worldview (Hasan, 2020).

\section{REFERENCE}

1) Abuza. (2009). The rehabilitation of Jemaah Islamiyah detainees in South East Asia: A preliminary assessment. In T. Bjorgo , \& J. Horgan, Leaving terrorism behind: Individual and collective disengagement (pp. 193-211). New York, NY: Routledge.

2) Aji, A. M. (2013). PEMBERATASAN TINDAK PIDANA TERORISME DI INDONESIA: Analisis Terhadap UU No. 15 dan 16 Tahun 2003 Berdasarkan Teori Hukum. Jurnal Cita Hukum, Vol. I No. 1 Juni 2013.

3) Altier, M. B., Boyle, E., \& Horgan, J. (2017). Returning to the Fight: An Empirical Analysis of Terrorist Re-engagement and Recidivism. Conference: International Studies AssociationAt: San Francisco, CA.

4) Altier, M. B., Horgan, \& Thoroughgood, C. (2012). In Their Own Words? Methodological Considerations in the Analysis of T Analysis of Terrorist A orist Autobiographies . Journal of Strategic Security 5, no. 4 (2012) : 85-98. .

5) Altier, Mary Beth, Thoroughgood, Christian N, \& Horgan, John G. (2014). Turning away from terrorism: Lessons from psychology, sociology, and criminology, Journal of Peace Research, Vol. 51(5) 647-661 


\section{Desistance From Terrorism a New Hope for the Quit from Terrorism Program in Indonesia}

6) Altier, Throughgood, \& Horgan. (2014). Turning away from Terrorism : Lesson from psychology, sociology, and criminology. Journal of Peace Research. Vol. 51 (5). 2014. 647-661.

7) Berg, M., \& Huebner. (2011). Reentry and the ties that bind: An examination of social ties, employment, and recidivism. Justice Quarterly, 28, 382-410. .

8) Bjorgo, T. (2019). Processes of disengagement from violent groups of the extreme right. In T. Bjorgo, \& Horgan, Leaving terrorism behind: Individual and collective disengagement (pp. 30-48). . New York, NY: Routledge.

9) Brame, R., \& Bushway. (2003). Examining the prevalence of criminal desistance. Criminology, 41, 423-448.

10) Chalmers, I. (2017). Countering violent extremism in Indonesia: Bringing back Countering violent extremism in Indonesia: Bringing back. Asian Studies Review, 41(3), 331-351.

11) Farrall, \& Maruna. (2004). Desistance-focused criminal justice policy research: Introduction to a special issue on desistance from crime and public policy. Howard Journal of Criminal Justice, 43, 358-367.

12) Farrington, D. P., \& Hawkins. (1991). Predicting participation, early onset, and later persistence in officially recorded offending. C. Criminal Behavior and Mental Health, 1, 1-33.

13) Farrington, David P. (2007). Advancing Knowledge About Desistance, Journal of Contemporary Criminal Justice, Vol 23 (1)

14) Horgan, John. (2008). Deradicalization or Disengagement?: A Process in Need of Clarity and a Counterterrorism Initiative in Need of Evaluation, Perspectives on Terrorism, Vol. 2, No. 4 (February 2008), pp. 3-8

15) IPAC. (2020). TERRORISM, RECIDIVISM AND PLANNED RELEASES IN INDONESIA. IPAC Report No. 66.

16) LaFree, \& Miller. (2008). Desistance from terrorism: What can we learn from criminology? . LaFree, G., \& Miller, E. (2008). Desistance from terrorism: What can we learn from criminology? Dynamics of Asymmetric Conflict, 1(3), 203230. doi:10.1080/17467580902718130.

17) Laub, \& Sampson. (2001). Understanding desistance from crime. Crime and Justice, 28,.

18) Monahan, J. (2010). The individual risk assessment of terrorism. . Journal of Psychology, Public Policy and Law, 18, 167205.

19) Raets, S. (2018). The We in Me. Considering Terrorist Desistensi a Social Identity Perspective. . Journal of Deradicalization. Winter 2017/18.

20) Rosenfeld, R. (2008). Recidivism and its discontents. . Criminology and Public Policy, 7, 311-318. .

21) Schmid, P. Alex. (2013). Radicalisation, De-Radicalisation, Counter-Radicalisation: A Conceptual Discussion and Literature Review, ICCT Research Paper

22) Sumpter, C. (2017). Countering violent extremism in Indonesia: Priorities, practice and the role of civil society. Journal for Deradicalization, 11, 112-146.

23) Zulfahri, Y. (2020). Bayang-Bayang Terorisme:Potret Genealogi dan Ideologi Terorisme di Indonesia. Pustaka Milenia. 